\title{
ResearchArticle
}

\section{Impact of front line demonstrations (FLDs) on yield of pulses in NICRA villages of Bundelkhand region of U.P.}

\author{
D.K. MISHRA , K.K. SINGH, NISHI ROY AND VIKAS KUMAR
}

\section{SUMMARY}

The study was carried out during Kharif, Rabi seasons in NICRA villages of Hamirpur and Jhansi district of Bundelkhand region of Uttar Pradesh during 2014-15. All 255 demonstrations on pigeonpea, black gram, green gram, chick pea, fieldpea and lentil were carried out in area of 53.4 ha by the active participation of farmers with the objective to demonstrate the improved technologies of pulses production potential. The improved technologies consisting use of high yielding variety, seed inoculation with Rhizobium and PSB culture, integrated nutrient and pest management. FLD recorded higher yield as compared to farmer's local practice. The demonstrated technology recorded higher yield of $1160 \mathrm{~kg} / \mathrm{ha}$, $950 \mathrm{~kg} / \mathrm{ha}, 820 \mathrm{~kg} / \mathrm{ha}, 790 \mathrm{~kg} / \mathrm{ha}, 700 \mathrm{~kg} / \mathrm{ha}$ and $350 \mathrm{~kg} / \mathrm{ha}$ in chick pea, field pea, lentil, black gram, pigeonpea and green gram, respectively than 620,530,460,450, 420 and $230 \mathrm{~kg} / \mathrm{ha}$. Despite of yield increase the technological gap, extension gap and technology index were observed. The results indicated that improved technology gave higher gross return, net return with higher benefit cost ratio as compared to farmer's practices.

Key Words : Pulses, Yield, Technology gap, Extension gap, Technology index

How to cite this article : Mishra, D.K., Singh, K.K., Roy, Nishi and Kumar, Vikas (2017). Impact of front line demonstrations (FLDs) on yield of pulses in NICRA villages of Bundelkhand region of U.P. Internat. J. Plant Sci., 12 (2): 169-172, DOI: 10.15740/HAS/IJPS/12.2/169-172.

Article chronicle : Received : 05.04.2017; Revised : 09.05.2017; Accepted : 27.05.2017

\section{MEMBERS OF THE RESEARCH FORUM}

Author to be contacted :

D.K. MISHRA, Krishi Vigyan Kendra, Tatyora, HARDOI (U.P.)INDIA

Email : mishradk3@gmail.com

Address of the Co-authors:

K.K. SINGH, Krishi Vigyan Kendra, Dariyapur, RAEBARELI (U.P.) INDIA Email : kvkraebareli.1984@gmail.com

NISHI ROY AND VIKAS KUMAR, Krishi Vigyan Kendra, Bharari, JHANSI (U.P.) INDIA 